\title{
Treatment of Damages and Remuneration Practice in Compulsory Insurance Contract in Transport Sector
}

\author{
Juliana Bylykbashi ${ }^{1}$ \\ Enkelejda Softa (Metaliaj) ${ }^{2}$ \\ Ilda Mucmataj ${ }^{1}$
}

${ }^{1}$ Phd., Faculty of Law, Civil Department University of Tirana

2Ph.D. candidate, Judicial District Court, Tirana

Email: julibylykbashi74@gmail.com

Doi:10.5901/ajis.2015.v4n2s2p72

\section{Abstract}

Due to the dangerous nature of having and using motor vehicles, due to the frequency and intensity of damages caused by them, considered as source of danger, taking account the need to protect the interests of the thirds frequently threatened by road accidents, regarding the value, procedures and the reasonable necessary time to indemnify them, and in order not to impede the free movement of people and goods unreasonably because of road accidents, the legislator has approved a special legislation for insurance of civil responsibility of holders of motor vehicles towards the thirds. One of the fundamental principles of cohabitation in human society is the prevention to cause damage to someone else (alterum non laedere ose neminem laedere). Its application is provided in Civil Code, and especially in the provisions on civil extra-contractual damages, provided by articles 608 and its followings. Basing on this responsibility, known as "akuilian responsibility" (lex Aquilia de damno), "each one who violates the legal rights and interests of another one, has to indemnify him. Through indemnity it is exactly aimed to establish the injured one back (restitutio in integrum) to his previous situation (status quo ante), where he would be if the illegitimate fact did not happen. The unifying Sentence of United Colleges of Supreme Court of 12.09.2007, gave to the nonpecuniary damage category a new dimension, placing along with the moral damage part (non pecuniary nature of which is already consolidated) the existential damage part as well and the biological damage too. In function of security guarantee, of stability and uniformity of trial, to determine the grade of health harm and the respective extent of indemnity, in principle, the courts and experts refer to the table technical requirements, provided for this purpose, or for similar situations, in normative acts. The purpose of this paperwork is analyzing and treatment of damages coming from insurance contract of compulsory insurance in transport sector, the profiting subjects and the subjects obliged by law and the way of indemnification and the calculation of any damage caused because of an illicit fact.

Keywords: compulsory insurance, damage indemnity, biological damage, existential damage, moral damage

\section{Introduction}

The concept of compulsory insurance coming from using motor vehicles was born after the First World War with considerable augmentation of motor vehicles. ${ }^{1}$ Precisely, for the first time it was provided in United Kingdom by law "On road circulation" where it was provided that "Each car owner or driver has to be insured for the damage he causes to the thirds' life or property, during the time their vehicle circulates in public way" (Mataj, 2015)

In Albania the Civil Code of year 1981 provided the insurance contract, but only for property damages. The Civil Code of 1994 provides the voluntary insurance contract in articles 113-1161, giving provisions about property and person's insurance (life and health).

The compulsory insurance is a type of insurance, which legislator has determined with imperative norms, like a compulsory one because of risk from a big damage that may come from an insured event. (Bajrami, F, Krasniqi, A. Ibrahimi, Sh. Komani, N, 2012, 29). In many countries the insurance of vehicles is compulsory and especially compulsory the responsibility to the thirds. (Guri,Gjoni,Dervishi,2012). The compulsory insurance in the sector of transport includes²: a) The insurance of passengers from accidents in public transport; $b$ ) The insurance of responsibility of vehicle's owner or driver of motor vehicles, for the damages caused to the thirds from using this vehicle; c) The insurance of responsibility of owner or

\footnotetext{
1 The first private vehicle results in England, while the first motor vehicle police was in November of year 1896.

${ }^{2}$ Article 2, pg.1, of the law no. 10076 date 12.02.2009, for compulsory insurance in sector of transport.
} 
user of a plane for damages caused to the thirds and to passengers from using this kind of vehicle; d) The insurance of responsibility of the owner or user of a navigation vehicle for the damages caused to the thirds by using such vehicle.

\section{Research Methodology}

This paperwork is a theoretical research based on doctrine, but even on a lot of legal and sublegal acts which regulate this field of law. In order to understand this issue, the theory is illustrated with practice, analyzing and treating many court decisions of three grades of judiciary and decisions of constitutional court as well.

\section{The legal framework of damages in the field of transport}

The first legal act for compulsory insurance of motor vehicles for the responsibility to the thirds was the Decree no. 295/1992 and the Regulation 622/1 of year 1992. In any case, these legal or sublegal acts speak about "damage remuneration" without specifying it to a pecuniary or non pecuniary damage.

The unifying Decision no. 12, date 14.09.2007, of United Colleges of Superior Court, which has made the categorization of damage figures to the pecuniary one provided in article 640 and followings of the Civil Code and to nonpecuniary damage provided by article 625/a of the Civil Code, for non-pecuniary damage has made evident its 3 composing figures: the "biological damage", "the moral damage" and the "existential damage". After the unifying decision no. 12 of date 12 september 2007, the Minister of Finances issued the instruction "About treatment of damages covered by compulsory insurance contract of holders of motor vehicles for the responsibility to the thirds", where the remunerations were established for moral, biological existential and pecuniary damages.

Considering that in the field of transport it is very difficult to prevent coming of consequences of such serious damages, which affect such important and conventional constitutional values, the legislator has approved the law on compulsory insurance in the sector of transport, so that the injured persons can be reestablished in previous condition (status quo ante), as they were if the illegal fact did not happen. This law gives to the persons the right to ask for damage remuneration of pecuniary or non-pecuniary submitted.

The compulsory insurance contract is not provided in civil code but it is regulated with a special law. Even the general provisions of the Civil Code apply, and also in special arrangements of legislation on extra contractual damages of the thirds caused to the thirds by motor vehicles. The contract of compulsory insurance from using motor vehicles covers the damages/losses happened in Republic of Albania and in territories of green card.

The approval of law No. 10076 of year 2009, brought a specific provision of formula of calculation where it establishes general rules for each subject of insurance and the same standards for treatment and evaluation of payments of damages in the territory of Republic of Albania. By this special law the legislator completed the legal blankets existing in this field and which pushed and brought the need for interpretation of some general provisions of the Civil Code by the side of Supreme Court. In application of the above mentioned law, the board of Financial Supervising Authority which is the regulating and supervising authority in the field of insurances and re-insurances issued the regulation no.53, which content is the same as the instruction of MF no. 24/2007 to regulate the treatment of damages covered by the contract of compulsory insurance .

This question is debatable: does this regulation have to be applied by the side of the court, where the regulation in the hierarchy of laws is classified as a sublegal act and as such cannot have priority over the legal provisions, to articles $625,640,643$ and 646 of the Civil Code, provisions which provide the pecuniary and non pecuniary damage?

In order to answer to this question we should refer to article 119 of the Constitution of Republic of Albania which provides that "The regulations of Council of Ministers, of Ministries and of other central institutions, and the orders of Prime Minister, of ministers and of Directors of central institutions have the national character and are mandatory only for administrative units depending from them". "These acts are issued basing on the law and they can not serve as basis to take decisions relating to individuals and to other subjects". According to Decision No. 2, date 03.02 .2010 of the Constitutional Court of Republic of Albania, according to which "If the judge during a trial concludes that law and sublegal act which are directly related to the resolution of the case are in objection with one another, he has to respect the law. The judges should also take account the reports between the laws approved with qualified majority". According to Constitutional Court "The norm with higher power prevails the other one."

Secondly; in decision no. 293 date 27.05.2014 of the civil college of Supreme Court is expressed otherwise to what the law has provided, the instruction no. 24 of MF contains several determinations on sorts of damages and on their pertinent maximal values, for which is not delegated by law, for example in chapter II, II/b item 2 "The non pecuniary 
damage items 1 and 3 have the maximal values of indemnity, limits which have not been delegated by law. As a result in application of articles 118 and 135 of constitution, the court cannot refer to them and apply them in cases object of trial regarding the value of indemnity".

Thirdly, according to unifying decision no. 12/14 September 2007, as long as today, there are tables where indemnities can be measured, like the regulation of Financial Supervising Authority, as it is legitimated by law as well. Moreover this is in consistence with article 44 of constitution for rehabilitation from damage, basing on the law. In cases when the court notes provisions of sublegal act issued by an organ of central public administration like the Authority of Financial Supervision, it is contrary to the law or constitution and should not apply it. The civil college of Supreme Court as grounding the decision expresses that: "The determination of specific values on which basis are made the calculations and the determination of indemnity measures are issues of judicial investigation of each insurance case coming to be examined in court, considering the references based on values which can be provided by the legislation in force or can be identified or accepted by judicial practice, after having taken the opinion of experts of different fields of science.

After the decision no. 6 date 17 february 2012 of constitutional court the indemnities of compulsory insurance contract are arranged by the special law and not by unifying decision, which after issuance of the special law for this field lost its effect: "It already determines even the legal table criterions where the courts should be based on about determination of indemnity value which were absent at the time when the unifying decision was taken.

\section{Sorts of indemnities of extra contractual damages}

In general, the insurance of vehicles offers: cover of losses on property (vehicle) because of theft, cover of responsibilities and of medical expenses, of damages to the thirds because of accidents. According to the goal they have, the indemnities of extra contractual damages, theoretically are classified in: a) Indemnity with repairing rehabilitating character (it aims the reestablishing of damaged person to his previous condition. The repair can be in nature, rehabilitating him as he was, or in money, or of them both like the pecuniary damages). b) Reward with compensating character, which aims in restore of previous situation of the injured, replacing the damage with an object or action that "smoothes" the damage. It is typical in non pecuniary damages where it is intended to compensate damage with its value in money, c) The reward with punitive character, found more in Anglo-Saxon law where the indemnity more than to repair, compensate the damage of injured, is placed multiple higher to sentence the person in order not to make that action again, and demonstrate it to the society, d) The reward with symbolic character has more a satisfying character for the injured because of various circumstances and of small damage submitted, often used by European court of human rights in its decisions.

\section{The concept of pecuniary and non pecuniary damage indemnities}

The insurance reward is any sum for which the insurer owes to the insured, to the profiteer or to any injured party, which comes as a right from insurance contract or from insurance activity (according to the classes provided in annex I, of the law no.52/2014), including here the amounts set aside for the above mentioned as well, when some elements of obligation are still not known (article 4 item 12 of law no. 52/2014). The reward should be fair and should turn the injured back to the state he was as if it did not happen at all, and should not enrich the injured". It is based on principle that: "the remuneration should cover all the damage and nothing more than the damage". It should not be confused: the amount insured as a limit of insurer's responsibility for the damage submitted by the insured that must be remunerated within this limit of responsibility. This means that in every case the insured party should measure the damage submitted in his property and then this will be restituted within the insured sum. The fact that the insured insures his property in "a certain insured sum" does not mean that the damage submitted on his property is a priori equal to the insured sum. This insured sum is nothing more than a limit of responsibility and not a priori the value of damage submitted for the insured. ${ }^{3}$

Every person, who has been caused a damage with a transport vehicle within the territory of Republic of Albania has the right to ask for indemnity for losses or damages submitted which according to the case consist in: a) pecuniary damage: i.damage with consequence death, damage with provisory health injuries (partial/full) and permanent (partial/full); ii. material damage related to damage or destruction of property $b$ ) non pecuniary damage: biological damage; moral damage; existential damage.

The person who illegally and on purpose, causes to someone damage to his property or to his person is obliged to

${ }^{3}$ Decision no. 277 date 25.01 .2010 of Judicial District of Tirana. 
remunerate him the damaged caused (Article 608 of the Civil Code) which is composed of pecuniary damage, non pecuniary damage and the interests borne because of delay in realizing the full value of the damage.

The pecuniary damage in every case causes the infringement of the property of injured in narrow economic sense that means the loss of property illegally. Therefore, the remuneration aims to restitute the property of injured to its previous condition, filling the difference between the actual economic situation and the previous situation where the plaintiff was if the accident did not happen. Part of pecuniary remuneration is even the funeral expenses of the defunct, and expenses of rehabilitation of the injured ones.

Regarding the pecuniary damage, the articles 486 and 640 of the Civil Code distinguish the loss undergone because of reduction of property, which is recognized as actual damage or real damage (damnum emergens) and the lost profit (lucrum cessans). In principle the distinction between the real damage (quantum mihi abest) and the lost profit (quantum lucrari potui), ${ }^{4}$ stands in actuality or not of infringed patrimonial interest. In the first case the object of damage is reduction, loss of an actual patrimonial interest, so of a property that belongs (in re ipsa) to the injured at the moment of damage.

Non pecuniary damage, as a wide and comprehensive category of extra contractual damages, includes any type of damage submitted by infringement of non-patrimonial rights and interests which are part of human values and which are not a subject of direct economic evaluation on market. The article 625 of Civil Code recognizes the right of indemnity for any type of extra contractual non pecuniary damage, which is "different" from the pecuniary one. The order of "cases" of non-pecuniary damage in its paragraphs "a" and "b", does not intend to limit, but to regulate expressively the effects of distinguished infringements, the right of relevant remuneration and the circle of subjects who are legitimated actively.

According to the doctrine of our judicial and international practice, the harm of health is an autonomous figure of non-pecuniary damage, different from pecuniary damage for "loss and recution of skills to work" (article 641 of the Civil Code). While in the second group there are two figures of non-pecuniary damage, independent from one another, the moral damage and the existential one.

i. Health damage, known by jurisprudence as "biological damage" or "damage to health", is a special figure of non-pecuniary damage and as such, it is an independent object of research of its relevant indemnity. Unlike the pecuniary damages, the biological damage ha no economic value on the free market, its infringement is not remunerated in nature and there is no price in money for it. But, for the effect of health protection, of facilitation and physical and social rehabilitation of the injured in the future, the person responsible for causing the biological damage has to pay him a remuneration in money, regardless the other pecuniary or nonpecuniary damages which eventually the injured has undergone because of the same illicit fact, constitutes the infringement of good health, of physical and/or psychic integrity and has a negative effect to the primary routine activity, in dynamic and interpersonal life of the injured party, despite the possible return of his capacity to provide incomes.

ii. Moral damage, (pretium doloris ose pecunia doloris) is an interior, temporary demonstration of unfair perturbation (non iure perturbatio) of human spiritual condition, or anxiety and spiritual torment arising as a consequence of an illegal fact.

iii. Existential damage is the violation of rights of human personality harming the expressing of injured permanently, of his familiars in outer world, shocking his everyday life and his ordinary activity, the quality of his life and his personal and family relations. Due to such psycho-physical condition, the injured cannot perform any more certain activities, which characterized him positively or might have characterized him positively in the future, forcing him to align to various solutions in life different from what he wished or expected or giving up to the last ones because of an illicit fact happening.

\section{Subject of remuneration of pecuniary and non pecuniary damage}

\subsection{Beneficiary subjects}

All the persons who because of an accident have submitted one, several or all the categories of damages provided by law are entitled to ask for remuneration of damage. These persons according to the capacity conferred by law can be

4In case of lost profit we deal with incapability to profit a future pecuniary intrest, so of a property which still does not belong to the injured at the moment of damage cause". In this meaning the financial contribution the victim had in his family as employed is calculated by an indipendant expert as "lost profit", while the funeral expenses are in form of "a real damage". 
classified in 3 categories:

i. The passengers - are the ones, who travel by one of transport vehicles, destined for public transport, regardless the fact they have bought a ticket, including even the persons who are found in the territory of the station, or beside the transport vehicles, before climbing on or getting off, who intend to travel with a transport vehicle, excluding the ones employed by that transport company. Passengers are also called the ones who have the right to travel free. Comparing this definition with the other law provisions in general, these questions arise naturally: Will be considered passengers the persons who, though they meet the characteristics of passenger according to article 18 of LSDST, are damaged by motor vehicles who have no obligation to insure passengers, but only the responsibility towards the third parties?

In my personal opinion this person should be treated in capacity of passenger for some reasons: First, the law itself provides that except the passengers the persons who have undergone damage by a motor vehicle will be considered the thirds. Secondly, not without purpose the law has paid a special attention to the passengers differentiating them from third parties. In this way the legislator guarantees a particular protection to passengers. Lately, though the owner of vehicle has not obligation in this case to insure the passengers, the law does not ban him to make insurance contracts for passengers.

Will be considered passengers the persons who though they do not have the characteristics of passengers, they submit a damage by a motor vehicle of public transport?

It is easier for us to answer this question as law itself in its articles 18 and 20/2 answers to it. Considering that the person does not meet the characteristics of passenger he cannot be treated like him. This answer is reinforced by paragraph 2 of article 20 as well, which provides that when the owner of a transport vehicle, who has made a contract for insurance of passengers in public transport, is responsible for the damage incurred, every remuneration of damages to the injured parties, according to the insurance of responsibility, which results from using the transport vehicle, does not include the amount that belongs to the injured parties, according to the compulsory insurance of passengers from accidents in public transport.

ii. Third persons - are all those persons, other than passenger, who have been caused damage by motor vehicle. It is undisputable for this party to have submitted damage related to the motor vehicle and not by other types of accidents where the motor vehicles is not involved in the insurance event. So, the cause of death or health damage must have come from using a motor vehicle and not by other outer sources.

iii. Derived subjects (relatives of victims) - Every subject infringed in his personal legal rights and interests from an illicit fact, though he is not a passive subject of this fact, he has the subjective right, the active legitimacy to ask for (ius proprius) indemnity of damage incurred. This active legitimacy, in principle is not conditioned by having the capacity of successor of an injured person, but only with capacity of plaintiff himself as damaged by the illicit fact. So, anyone who certifies the legal causal connection between the illicit fact and the damage submitted in his legal rights and interests can refer to the insurance company, to Jury or Court to ask for the amount of indemnity he deserves referring to the legislation in force. I called them derived subjects because their right to benefit the indemnity for non-pecuniary damages is conditioned by another non pecuniary damage incurred to the main person, whose life or health has been damaged. This right, in quality of injured, belongs individually (ius proprius) to any of close familiars (including co-habitant) of the person who has lost his life or has had his health infringed by the unlawful fact, if certified their special family relation, sensitive and cohabitation one. The moral and existential damage submitted by the familiars themselves is considered a consequence, an immediate and direct consequence of the same unlawful fact.

\subsection{Obliged subjects}

1) The insurance company: a) "direct" - one is the insurance company, to which the owner of damaged motor vehicle has a contract for insurance of responsibility for damages caused to the thirds. This subject is obliged to indemnify the person only if he remains damaged from accident of two identified motor vehicles and insured with compulsory insurance contract to the thirds, and the insurance companies of both vehicles have a contract for such purpose. b) "responsible" - is the insurance company, to which the owner of transport vehicle who has caused the damage has an insurance contract of responsibility for damages caused to the thirds. $\mathrm{c}$ ) "authorized" - is the Bureau member company, to which the Bureau has delegated the competence forcing it 
to treat and pay the damage with compensation fund expenses. ${ }^{5}$

2) Albanian Bureau of Insurances - is the subject obliged to pay the indemnity in cases when the owner of a motor vehicle has not made a contract for insurance of passengers, and the accident has happened, the motor vehicle has not been insured for responsibility to the thirds and the accident has happened, or the motor vehicle which has caused a damage to a person is not identified or when the motor vehicle at the moment of accident has been illegally embezzled and in cases when the obliged insurance company is dissolved or goes bankrupt. The Bureau faces these obligations with the incomes of compensation fund. In all cases the Bureau has the right to ask from the responsible person the reimbursement of paid sum, of expenses and of payable interes and in case of refusal the Bureau can refer to the court with a regress lawsuit.

\subsection{Case of exclusion}

The general rule is that the subject has the right to address to the responsive company or to the bureau according to the case, in all cases when the injured has been damaged by an accident caused by a motor vehicle. But, as exclusion from this rule, the law provides several subjects who though they may injured by a motor vehicle, they do not have the right to be indemnified. ${ }^{6}$

The passenger who by his own will has been in the motor vehicle which caused the damage, driven by an unauthorized person cannot be covered. But the insurance company has the burden of proof to certify that the passenger was aware of these circumstances. An unauthorized driver is considered the person, who in case of accident has driven the vehicle without the permission of car's owner, or he has not been employed by him to drive the vehicle, or he is not a member of his family and the vehicle has not been consigned to him by the owner. In addition, the passenger who to his wish has been inside the uninsured vehicle which caused the accident is also uncovered from insurance but on condition that the bureau proves that the passenger was aware of this circumstance.

\section{Procedure of pecuniary and non pecuniary damage treatment}

In case of compulsory insurances, including those for coverage of responsibility of motor vehicles' drivers to the thirds, regarding the report between the insurance company and the insured, there is a contracting insurance relation, which is regulated in special legislation for compulsory insurances. For the issues between contracting parties which are not provided by the special law or are not differently regulated, the provisions of Civil Code for insurance contract are applied.

Whereas, regarding the issues related to the indemnity of damage, apply the provisions of special legislation for compulsory insurances and the provisions of Civil Code for extra contractual responsibility (articles 608 and its followings). The relation between the insurance company of insured on one side and of injured on the other side is a relation of extra contractual nature. If the special law does not provide otherwise, the provisions of Civil Code for extra contractual responsibility are applied.

It is important that in case of an insured case happening the person who has undergone a pecuniary and/or non pecuniary damage from this fact and wants to benefit from the indemnity right, first should notify about the insurance event to the pertinent obliged subject. The notification can be made in written or electronically. However the notification can be made even at the time of submitting the request for indemnity. The request must be always in written. Such request of form is more necessary for proving effect (ad probationem) than validity (ad validem). This request must be also accompanied by the required documentation according to the regulation of Financial Supervising Authority to fulfil the general and specific documents regarding the file of health or pecuniary damage through which the insurance event is attested, the circle of benefiting subjects is determined and the amount of respective remuneration is calculated for each one.

\footnotetext{
${ }^{5}$ Article 42 chapter V, of the law no. 10076, date 12.02.2009, (amended)

${ }^{6}$ According to article 23 of the law no. 10076/2009 for compulsory insurance in the sector of transport, amended: a) the driver of vehicle, the cause of accident; including here his legal heirs, for pecuniary and non pecuniary damages; b) the owner, co-owner and any other user of vehicle, cause of accident, for damages they submit from this accident; c) the person, who has embezzled the motor vehicle unlegally and has been damaged using this vehicle; d) the injured person in these cases: 1) due to use of a vehicle in sportive events on the road or road segments, prohibited to drive on, for driving with moderate high speed or to train for races. 2) due to consequences of nuclear energy during transport of radioactive substances; 3) due to actions of war, riots or terrorist acts, provided that the insurance company proves that the damage was caused by such events.
} 
Unlike the notification for which there is no defined term within which it must be done, the Regulation of Financial Supervising Authority for treatment of damages covered by the Contract of Compulsory Insurance in the Sector of Transport provides that the request for indemnity should be done by the injured within 2 years since the date of accident. The determination of such term of Financial Supervising Authrority seems to have been influenced by provisions of the Civil Code for prescription of the right of suing for claims that come from damage indemnity according to the insurance and reinsurance contract, and of the relevant amount derived from compulsory contract where it is said: these lawsuits are prescribed in 2 years, term that starts the day when the right to sue is raised. From the way of formulation, this term is preclusive and basing on its features it does not allow any suspension (except the cases provided by law expressively) and no interrupting as well. The only way to interrupt its proceeding is the direct submission in court with a lawsuit to ask for the innate subjective right.

Secondly, the liability relation created between the benefiting and obliged subjects is always an extra contractual relation because the injured person has no other legal relation with the insurance company except that of damage remuneration that the insured person has caused to him. The liability of the company to remunerate the damage to that person does not come from a contract entered between them but from the law itself. So the term of prescription for such sort of liabilities is 3 years and not 2 years. Moreover, this term is not preclusive, because it does not start on the day when the person has the right to sue but on the date when he knew or had to know about the damage submitted and about the person who caused it. But considering that his right to address to the responsible company or to the bureau, according to the case, is provided in LSDST then this term begins on date when the person has the right to sue because his awareness about this right to benefit from LSDST is presumed. Applied in the field of compulsory insurance in the sector of transport, this right of the person is not prescribed any more at the moment the injured is aware of the person who caused the damage, but after knowing that this has come because of an accident caused by a motor vehicle which had the obligation to be insured according to the law.

In case of submission of the request for indemnity to the obliged subject the latter has the obligation that after having it registered, he deals with its treatment and then notifies the interested subject in written about the amount of indemnity or about the refusal of request for indemnity mentioning also the reasons of refusing the request. This notification has to be made by the responsible company within 90 days, the remuneration of non pecuniary damage from the date of filling the damage file, and 30 days for remuneration of pecuniary damage (in case of non remuneration the insurance company has also to pay the payable interest for each day of delay calculated according to the legal usuries referring to article 450 of the Civil Code, where in their absence according to the norms of interests established by the Bank of Albania for non-term deposits, where concerning this, such indemnity consists in usuries reached since the beginning date of delay, ending at the moment of fulfilling the principal liability. Here comes the question: can the injured person make a lawsuit in court directly, without first referring to the responsible company for the indemnity of incurred damage that means without exhausting the administrative way? The injured person can make a lawsuit directly in court, without making first a request to the responsible company, for indemnity of non pecuniary damage. He also can refer to the court even if he has referred to the insurance company first and the procedures for treatment of damage are in progress and the term of 90 days as provided by the regulation of Financial Supervising Authority has not expired yet. This term serves to prevent the potential abuses of insurance companies, for cases when the subject is first directed to the insurance company. The extrajudicial way of resolving claims of subjects who benefit from the above mentioned legal act is a form of resolving disputes that may be raised but not a compulsory way to be exhausted from them before referring to the court .

This happens due to the fact that the insurance company is a private legal person and a subject of private/commercial law as well. Considering the importance in public services of the field where such type of company exercises its activity, this type of activity is provided by a special law too. In the context of administrative legislation, trade one and that applied in the field of motor vehicles insurance, the insurance company is not a subject of administrative law and it does not practice a state power but it has an executive-ordering activity. The activity of the field of insurances is not regulated by norms of administrative law. As a result even the insurance company, but even the thirds, physical or legal subjects, private or public ones, for the potential disputes between them because of insurance contracts of motor vehicles apply the provisions made by the Code of Administrative Procedure and the subjects who pretend for rights deriving from such contracts are not forced to apply any other way or "the administrative one" before referring to the court.

Regarding the biological damage, being an infringement to the physical and/or psychic integrity of the person, is objectively verifiable. So, in application of principal regulations of articles 2, 6, 29 and followings of the Civil Procedure Code (da mihi factum, dabo tibi ius), the injured who asks for indemnity has the burden of proof to certify that the damage 
has happened, and to also prove the causal relation with the illegal act. The proof burden to certify the moral damage belongs to the injured. But, considering the subjective nature of such damage and especially its character, its interior demonstration, the proof of infringement of the injured with perturbations, spiritual pains and suffering, etc. cannot be proved otherwise than by assessing ius receptum as based on the law and evaluating them as proved ipso iure by attestation from the plaintiff of the illegal fact of the thirds and of its relation with incurred moral infringement, according to the principle of causal regulation. Being evidence in form of a simple presumption, if the person who caused the damage does not reach to prove the opposite, it takes the same value and full proving power as the legal presumption iuris tantum (article 13 of the Civil Procedure Code).

In case of health damage or death of a relative, the court determines according to the case circumstances the specific circle of persons who have active legitimacy to ask for indemnity of moral damage ius proprius individually. In general, each person who belongs to the nearest family relation with the health injured person, exactly with the victim is actively legitimated. In the circle of persons who have active legitimacy are included, in same position with the minor child and spouse, namely, the child when born alive and the person who certifies the existence of sustained feeling and economic (more uxorio) cohabitation with the injured or the victim. The one who caused the damage has the burden of proof to certify the opposite.

Meanwhile the existential damage, not having simply a sensitive and interior nature, as an outer demonstration of infringement of legal interests related to quality of life, different from the moral one, is objectively verifiable and can not be proved only by simple presumptions. The court should accept only those real infringements of the rights of personality which has asked for and which are claimed by the injured as an existential damage submitted by him. Being subjective infringements by nature and closely related to the person of injured, he has the burden of proof to attest with positive evidences the alteration in aggravating meaning of equilibrium, of life routines and of his personal existence because of an unlawful fact (Onus probandi incumbit actori).

\section{The calculation of pecuniary and non-pecuniary damage in the field of compulsory insurance in transport sector}

The calculation of pecuniary damage is made separating the vehicles in three categories according to time of use/of production. ${ }^{7}$ In calculation are taken account: depreciation of vehicle, the actual value and its technical condition, the possibility of insurance of spare parts, the repairs.

Regarding the health damage with result death (understanding it as a property damage for his familiars because of death of their familiar) in the civil code (article 643 of the Civil Code) are calculated the expenses for food, living of minor kids, of spouse, of incapable spouse to work on charge of the defunct, calculating the others who had the right of food. In the value of indemnity with result death, are included even the expenses of funeral in fix amount of $250.000 \mathrm{All}$.

The biologic damage is benefited by the injured person according to the grade of incapability determined by the report of forensic experts Commission, or in case of death, by legal heirs. According to legal provisions ${ }^{8}$ the indemnity for permanent incapability to work (health aggravation) is calculated taking account the loss of skills to work for the additional value of damage considering the hospital costs, pharmaceutical costs, transport, the psychologist costs etc.

What does it mean health aggravation? The article 642 of the Civil Code is the article which indirectly stops on remuneration of damage caused to health and which affects the aspects of biological damage: the amount of damage remuneration can change in the future, depending on health improvement or aggravation, or on increase or decrease of working skills of the injured, in comparison with time of assigning the remuneration and of changes that the salary of the injured may have submitted". This arrangement unlike the Italian legislation is not expressively referred to capability to create material goods, but it refers to the salary and incomes that are lowered as a result of reduction of working skills of the injured. (Tutulani, 2007, 16) Regardless this fact, our legislation provides this biological damage as a pecuniary damage to health.

The indemnity for temporary in capabilities to work (health damage) is calculated according to article 19 of the above mentioned regulation, for incapability that lasts up to 6 months. When the injured has previously worked, as

\footnotetext{
7 The first category-the vehicles which entered in circulaton for the first time 4 years before the date of damage

The second category- the vehicles which entered in circulation 6 years before the first group, so 10 years before the date of damage;

The third cageory-vehicles produced/entered in circulation before the second group.

8 In regulation 53/2009 of Financial Supervision Authority the indemnity is provided according to the formula provided in article 16 
referring point for indemnity will be considered the salary of an employee of that category on which his work can be equal to or the work the injured could have done. Even the minor of 16 years old or when he becomes 18 has the right to ask for a calculation of indemnity with average salary of an employee of the category he would have gained if the accident did not happen. When the injured has not previously worked then the referring salary will be the minimum official salary. It must be careful: as minimal salary will be considered the one on date of liquidation and not the one of the date of accident.

Regarding the assigning of moral indemnity, in order not to be symbolic or an unjustified enrichment tool, the indemnity for a moral damage is assigned by the court in the limits between $1 / 4$ to $1 / 2$ of the amount previously assigned from it as an indemnity for permanent biological damage or in the same value as the one for temporary biologic damage. If the moral indemnity is demanded for loss of life of a relative, to assign it according to the above mentioned reports, the reference is made to the "terminal" biologic damage, where if he survived, the victim would benefit an indemnification in the amount of $100 \%$.

To assign the remuneration of existential damage, in cases of death or serious health damage of relative, even the grade of blood relations is taken account, the age of victim or of injured, the family composition and the condition of spouse, and also other circumstances which prove the aggravation of situation up to impossibility of expressing skills of injured to develop the everyday interests and activities. The determination of all these elements in calculation of this damage requires only to personalize case by case the treatment and assessment of such damage, which cannot have the same patterns in various cases and it cannot unify what has been experienced by injured persons for good of their health, on their physical and/or psychic integrity with a fixed value. Like the moral damage, even the existential one has a subjective nature. Therefore, the amount of indemnity is established despite the moral damage, but applying the same criterions and methods valid for indemnity calculating of the latter. ${ }^{9}$

\section{Limit of damages coverage (responsibilities) by insurance companies}

The parties in the insurance contract can set coverage limits higher than the legal ones. The limit of responsibility of insurer for indemnity on day of accident is provided this way: the limit of coverage of responsibility to the thirds on day of accident, regardless the calculations made according to articles 29 and 30 of regulation should not exceed the limits provided in article 26 of the Law No. 10076, date 12.02.2009 for SDST.

From a simple analysis we can make to ciphers mentioned in the article as above we can understand that the minimum limit of responsibility of responsible company or entity, according to the case, for non-pecuniary damage for a sole person is 4.500000 All, which summed up to the other damages of the same accident cannot exceed the limit of 20 000000 All. Exceptionally, these limits can be exceeded when in the insurance contract it is established a higher sum.

If there are several parties injured by an event and the total value of damage exceeds the sums mentioned above the rights of the injured parties versus the insurance company are reduced proportionally. Certainly, for the calculation of damages should be considered the measures of damage occurring at the time of the accident and not that of the moment in which an application for compensation or claim arises.

This question arises referring to the above mentioned: if the calculated damage is higher than the minimum limit foreseen above and a higher amount is not foreseen, can the person who has submitted the damage refer to the causer of damage for the part remained uncovered from insurance company? The answer of this question is regulated in article 608 and followings of Civil Code for extra contractual responsibility. Basing on this responsibility, known as "aquilian responsibility" (lex Aquilia de damno), whoever violates the legal rights and interests of another one has to indemnify him. Through indemnification it is intended the full return of injured (restitutio in integrum) to the previous condition (status quo ante), where he was if the unlawful fact did not happen.

\section{Conclusions}

The indemnification institute in compulsory insurance regarding the non-pecuniary damage is enriched after the issuance of unifying decision of Supreme Court. The issues encountered in practice related to the measure of indemnity and sorts

\footnotetext{
9 It is excluded only the calculation of value of existential damage that the injured person benefits in case of permanent total damage of his health (incapability scale 100\%). In this case the injured benefits from $1 / 2$ to $3 / 2$ of biological damage, unlike the moral damage which in this case is compensated from $1 / 2$ to twice of biological damage according to the respective age. From this value the familiars of the injured person can not receive more than $1 / 3$ of profit's value.
} 
of indemnity are more noted because of variety of decisions of judicial jurisprudence in three instances of judiciary system.

The Unifying Decision of United Colleges of Supreme Court no.2 date 14.09.2007, for the first time integrated in Albanian jurisprudence the figure of existential damage which was less known or not known at all by judges or other lawyers. The real damage is an independent figure in the category of non-pecuniary damage enlarging the dimensions of this kind of damage. So, Albanian judicial practice along with the other figures of non-pecuniary damage, already knows the existential damage and it realizes its remuneration if the conditions established by law exist. In the analysis of afore mentioned provisions we can reach to the conclusion that the fundamental premise to benefit a moral and existential damage is the existence of biological damage in the phase of permanent damages certified by Medical Commission of Assigning skills to work.

It is also worthy to make evident the great role and importance of their jurisprudence and legal doctrine in giving sound arguments about application of legislation in the field of insurances.

After the decision of constitutional court of year 2012 the remunerations of compulsory insurance contract are provided by a special law and not by unifying decision of 2007. Although from judicial practice it results that the court refers more to the variant of Supreme Court for non-pecuniary remuneration.

The legislation in the field of insurances should be in harmony with European legislation too. From June 2007 the pecuniary and non-pecuniary damages incurred to pedestrians, bikers and road users (not drivers of motor vehicles) are the new category of remunerations in EU. In addition even the familiars of persons who have undergone the accident are not excluded but considered as injured party as well. Eventually, basing on Directive 72/166/EEC "For insurance of civil responsibility that results from using motor vehicles and the application of obligations that insure such responsibility", on Directive 84/5/ECC "For approach of legislation related to insurance of civil responsibility that results from using a motor vehicle", amended by directives 88/357/EEC, 90/232/EEC.

\section{References}

Bajrami, F, Krasniqi, A, Ibrahimi, Sh, Komani, N, "Contracts on compulsory insurance" (2012), Judicial Institute of Kosovo, Justicia, pg.29 Galgano, Francesco, (1999) Private Law, The Publishing house "Luarasi", Tirana

Guri, Gjoni, Dervishi (2012) "Basis in insurances", The Publishing House "Albpaper", Tirana

Tutulani, M, (2007) Non Pecuniary (moral) damage under legal provision of the Civil Code, Legal journal, pg.16

Mataj, R (2015), Continuing Treatment, School of magistrates

Constitution of Republic of Albania (1991)

Civil Code of Republic of Albania (abrogated) of year 1981,

Civil Code of Republic of Albania, of year 1994,

Decree 295/1992 approved by law 7641/1992" (abrogated)

Regulation 622/1 (1992): For the application of compulsory insurance, (abrogated)

Law no. 10076 (2009): For compulsory insurance in sector of transport

Law no. 9572, (2006): For the Authority of Financial Supervision, modified

Regulation no. 53/ 2009 of Authority of Financial Supervision: For treatment of damages covered by the compulsory insurance contract in sector of transport.

Law no. 52/2014:On insurance and reinsurance,

Unifying decision no. 12, date 14.09.2007, of United Colleges of Supreme Court

Decision no. 277 date 25.01.2010 of Judicial District Court of Tirana

Decision No. 2 date 03.02.2010 of Constitutional Court of Republic of Albania

Decision No. 293, date 27.05. 2014 of civil college of Superior Court

Decision No. 6, date 17 February 2012 of Constitutional Court

Decision No. 27, date 10.01.2013 of Civil College of Supreme Court

Decision No. 311 date 01.07.2010 of Civil College of Supreme Court 